\title{
Global health training in paediatric residency programs: the Italian experience
}

\author{
Daniele Roncati ${ }^{1 *}$, Salvatore Aversa' ${ }^{1}$, Andrea Bon ${ }^{1}$, Alessandro Mazza', Davide Vecchio ${ }^{1}$, Liviana Da Dalt ${ }^{2}$ \\ From 71st Congress of the Italian Society of Pediatrics. Joint National Meeting SIP, SIMGePeD, Study Group \\ on Pediatric Ultrasound, SUP Study Group on Hypertension \\ Rome, Italy. 4-6 June 2015
}

Osservatorio Nazionale Specializzandi Pediatria (ONSP) is an Italian association of residents in paediatrics, and one of its interests is to support paediatric training in developing countries. In 2014, for this purpose, ONSP performed a survey with the aim of describing interest, participation, resources, and obstacles of residents who are involved in global health training within paediatric residency programs. Once the final data were known, an informative brochure was produced for publicizing the results of this survey and the projects that Italian Pediatric Schools have activated in developing countries.

35 of 38 paediatric residency schools (92\%) participated in the survey. $67 \%$ of them offer an elective training program in global health and $42 \%$ have a formal program that is part of the curriculum of trainees. $47 \%$ of the paediatric residency schools have a collaborative program with developing country or non-governmental organization (NGO) and 17\% had a program in the past years but not still ongoing.

In most cases, $3^{\text {rd }}, 4^{\text {th }}$ and $5^{\text {th }}$ year paediatric trainees were involved in "global health" training. The duration of training was less than 1 month in $13 \%$ of cases, $1-3$ months in 39\%, 3-6 months in $43 \%$, and more than six months in $4 \%$.

Only $22 \%$ of residents who were involved in training in developing countries were evaluated before departure, and only $35 \%$ received training in global health before leaving; $39 \%$ participated in post elective debriefing meetings.

$74 \%$ had the supervision of a local tutor (66\% pediatricians, $34 \%$ other doctors) and $61 \%$ also had an Italian tutor for the whole project.

Almost all of the collaborative programs were in Central or Southern Africa; only two of them were in Central America (Nicaragua).

\footnotetext{
* Correspondence: dani.roncati@gmail.com

'Osservatorio Nazionale Specializzandi Pediatria (ONSP), Padua, Italy

Full list of author information is available at the end of the article
}

The training in global health provided child care (in $62 \%$ of cases), neonatal care (45\%), malnutrition support (58\%), HIV prevention and AIDS care (20\%) and local staff training (42\%).

All residents were satisfied after their training in developing countries and only a few of them suffered for some minor reasons during that period.

In conclusion, more than $50 \%$ of Italian paediatric residency programs actually offer an elective program of global health program and most of the trainees consider it a great opportunity for professional growth.

\section{Authors' details}

'Osservatorio Nazionale Specializzandi Pediatria (ONSP), Padua, Italy.

${ }^{2}$ Department of Paediatrics, University of Padova, Padua, Italy.

Published: 30 September 2015

doi:10.1186/1824-7288-41-S2-A62

Cite this article as: Roncati et al:: Global health training in paediatric residency programs: the Italian experience. Italian Journal of Pediatrics 2015 41(Suppl 2):A62.

Submit your next manuscript to BioMed Central and take full advantage of:

- Convenient online submission

- Thorough peer review

- No space constraints or color figure charges

- Immediate publication on acceptance

- Inclusion in PubMed, CAS, Scopus and Google Scholar

- Research which is freely available for redistribution 